\title{
Kebijakan Pemberantasan Peredaran Narkoba di Indonesia dan Meksiko: Sebuah Studi Perbandingan
}

\author{
Randhi Satria dan Nyphadear Tiara S. A. P. \\ Universitas Sebelas Maret
}

\begin{abstract}
Many countries are trying to fight against drugs, but it is not easy as drugs have very high economic value. This make the producers and distributors keep struggling to expand their markets for getting larger profits and fulfilling the demand of those markets. Basically, Indonesia and Mexico face the same problem, drugs circulation. Both countries use different approaches which resulted on the different impacts from the implementation. This paper discusses about the implications from those differences on the same policy to fight against drugs.
\end{abstract}

Keywords: Indonesia, Mexico, Drug, Comparison, Policy

\begin{abstract}
Abstrak
Banyak negara yang berupaya memerangi dan memberantas narkoba. Namun, bukan hal yang mudah mengingat narkoba memiliki nilai ekonomis yang tinggi. Sehingga membuat produsen dan distributor terus berupaya melakukan ekspansi pasar demi meraih keuntungan dan memenuhi permintaan. Pada dasarnya Indonesia dan Meksiko menghadapi masalah yang sama yaitu peredaran narkoba tetapi kedua negara menghadapinya dengan menggunakan pendekatan yang berbeda. Hal tersebut tentunya memberikan dampak yang berbeda pula. Pertama, esai ini membahas persamaan dan perbedaan yang dihadapi oleh kedua negara tersebut. Kemudian membahas implikasi dari perbedaan tersebut ketika dihadapkan pada kebijakan yang sama yaitu kebijakan pemberantasan narkoba.
\end{abstract}

Kata-kata kunci: Indonesia, Meksiko, Narkoba, Perbandingan, Kebijakan

\section{Pendahuluan}

Indonesia dan Meksiko merupakan dua negara yang sedang melawan dan berupaya keluar dari jeratan peredaran narkoba yang menjadi ancaman stabilitas keamanan di negaranya. Peredaran narkoba yang terjadi di level domestik kedua negara sudah mencapai level yang mengkhawatirkan. Sifat narkoba yang sangat merusak telah menyerang berbagai kalangan mulai kalangan muda hingga dewasa.

Upaya pemberantasan peredaran narkoba bukanlah pekerjaan yang mudah. Dibutuhkan komitmen dan keseriusan dari pemerintah yang sedang menjabat demi keberhasilan program tersebut. Beberapa 
jenis pendekatan dapat digunakan oleh pemangku kekuasaan baik menggunakan soft power seperti authority dan influence maupun hard power seperti penggunaan force dalam agenda pemberantasan narkoba.

Tulisan ini menggunakan konsep power dalam menjelaskan pendekatan yang digunakan oleh pemerintah dalam menegakkan stabilitas keamanan melalui penegakan order. Hal tersebut menjadi penting mengingat tanpa adanya order yang berlaku dalam masyarakat maka jelas yang terjadi adalah masyarakat yang tidak tertata dengan baik sehingga mengakibatkan batasan yang mengabur antara yang legal dan ilegal.

Penggunaan dari salah satu unsur power kemudian dianalisis dalam teori decision making process untuk melihat lebih jauh alasan yang melatarbelakangi masing-masing pemangku kebijakan, dalam hal ini pemerintah, dalam memutuskan penggunaan salah satu unsur power yang ada. Persamaan dan perbedaan yang terdapat dalam analisis ini akan dianalisis menggunakan metode perbandingan politik untuk memberikan penjelasan lebih lanjut.

\section{Kerangka Analisis Studi Perbandingan}

Metode yang digunakan dalam esai ini adalah metode perbandingan politik. Perbandingan politik digunakan untuk melihat proses deskripsi dari fenomena politik dan kejadian-kejadian tertentu dalam suatu negara tertentu atau beberapa kelompok negara tertentu (Landman, 2008). Fenomena politik yang terjadi di beberapa negara dalam skala kecil kemudian dibandingkan satu sama lain untuk menghasilkan persamaan dan perbedaan dari latar belakang pengambilan suatu kebijakan politik dan konsekuensi yang dihasilkan dari kebijakan tersebut.

Strategi komparasi yang digunakan dalam penelitian ini ialah Most Similiar Systems Design (MSSD) sebagaimana yang dijelaskan oleh Ackar (2011). Peneliti membandingkan dua atau lebih kasus dengan variabel pembanding yang nilainya sama namun output yang dihasilkan berbeda. Adapun variabel pembanding yang digunakan oleh peneliti untuk mengomparasikan kebijakan Indonesia dan Meksiko dalam hal pemberantasan narkoba adalah willingness dari pemerintah kedua negara, jaringan narkoba internasional yang berada di kedua negara tersebut, dan respon dari masyarakat di kedua negara tersebut. Adapun hasil output dari kebijakan tersebut berbeda di kedua negara.

Untuk menjelaskanlebihlanjut fenomena pemberantasannarkoba antara Indonesia dan Meksiko maka penulis perlu menjelaskan terlebih dahulu konsep yang digunakan untuk menganalisis penggunaan power dari masing-masing negara. Hal ini penting karena unsur-unsur power tersebut dapat memberikan gambaran lebih rinci tentang kebijakan 
politik seperti apa yang diambil oleh masing-masing negara dalam pemberantasan narkoba.

Tentunya sebelum membahas lebih dalam mengenai konsep power, akan lebih sempurna lagi ketika kita terlebih dahulu membahas mengenai teori decision making process (DMP) atau teori proses pembuatan kebijakan. Mempelajari teori DMP ini dirasa penting karena pada hakikatnya power yang akan dibahas nanti merupakan sebuah decision yang dihasilkan oleh sebuah proses. Salah satu pakar DMP, Hansson (2008) menjelaskan bahwa DMP adalah segala teori yang berkaitan dengan decision. Selanjutnya Hansson menjelaskan bahwa ada banyak sekali teori, pendekatan, dan model yang menjelaskan mengenai bagaimana suatu pihak menjalakan sebuah proses yang berujung pada diambilnya sebuah keputusan. Salah satu model tersebut yang paling cocok untuk diterapkan dalam penelitian ini ialah model modern sekuensial atau modern squential model.

Hansson (2008) menjabarkan bahwa modern squential model menekankan pada pemecahan masalah (problem-solving), sehingga sangat cocok untuk diterapkan pada masalah-masalah yang sangat sulit untuk diselesaikan. Masalah-masalah tersebut pasti memiliki kesulitan untuk dipecahkan, dimana pada tiap kesulitan tadi pasti memiliki karakternya sendiri-sendiri. Oleh karena itu, diperlukan sebuah proses yang menyeluruh untuk menghasilkan sebuah decision guna memecahkan masalah tadi.

Dalam model tersebut, ada lima langkah yang harus dilalui dalam proses pembuatan keputusannya. Kelima langkah tersebut meliputi: identifikasi masalah, mencari informasi yang dibutuhkan, menghasilkan solusi yang realistis, mengevaluasi solusi yang telah diterapkan, dan menerapkan strategi untuk performa selanjutnya. Selain itu, Hansson (2008) juga menjelaskan bahwa dalam modern squential model ada tiga prinsip yang harus dipegang. Ketiga prinsip tersebut ialah mencari kesempatan terbaik untuk membuat keputusan, mencari cara-cara terbaik untuk menerapkan keputusan, dan memilih salah satu cara yang terbaik untuk diterapkan. Hansson menjelaskan dalam bahasa yang lebih sederhana bahwa prinsip yang pertama merupakan intelegensia, prinsip kedua adalah design, dan prinsip yang ketiga sebagai pilihan. Untuk lebih memahami mengenai modern squential model sebagai salah satu teori DMP, perhatikan tabel berikut: 


\section{Tabel 2 Modern Squential Model}

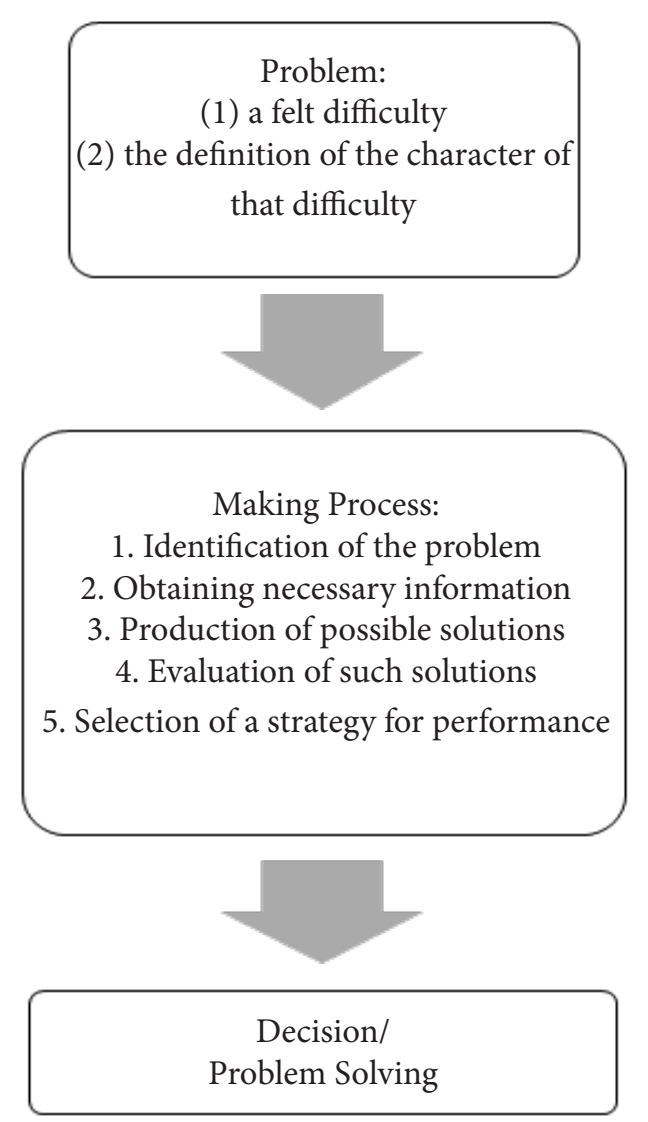

Sumber:Hansson, 2008

Setelah memahami mengenai modern squential model sebagai salah satu model dalam DMP, maka selanjutnya akan dibahas mengenai konsep power. Couloumbis dan Wolfe (dikutip dalam Mas'oed, 1994) mendefinisikan power merujuk pada apa saja tindakan yang bisa menciptakan dan mempertahankan pengendalian aktor A terhadap aktor B. Dalam hal ini power bisa dilihat memiliki tiga unsur penting. Pertama adalah force, bisa didefinisikan sebagai ancaman eksplisit atau penggunaan militer, ekonomi, atau sarana pemaksa lainnya oleh aktor A terhadap aktor B demi mencapai tujuan politik A. Kedua adalah influence, bisa didefinisikan sebagai penggunaan alat-alat persuasi (tanpa kekerasan) oleh aktor A demi menjamin agar perilaku aktor B sesuai dengan keinginan aktor A. Ketiga adalah authority, yaitu sikap tunduk sukarela oleh aktor B pada arahan (nasehat, perintah) yang diberikan oleh aktor A. Konsep power bisa digambarkan dalam skema sebagai berikut: 
Tabel 2 Unsur-unsur power

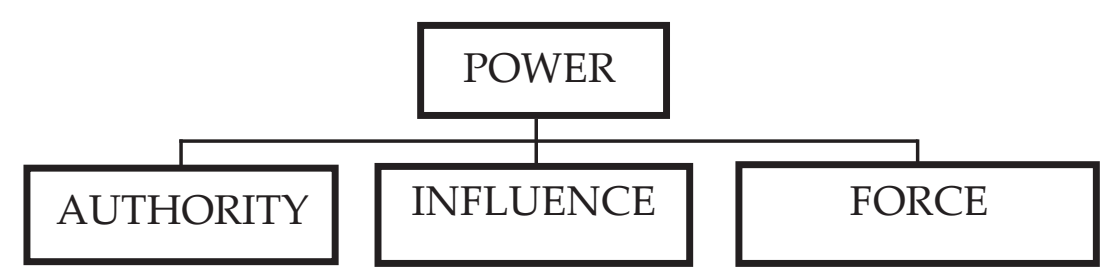

Sumber: Mas'oed, 1994:119

Indonesia dan Meksiko telah menggunakan tiga elemen dari power sebagaimana yang dijelaskan di atas tetapi dengan kadar yang berbeda. Tentu saja hal tersebut disesuaikan dengan kebutuhan dari masing-masing negara dalam mengaplikasikan kebijakannya. Aplikasi dari kebijakan yang diambil oleh Indonesia dan Meksiko tentu memberikan hasil yang berbeda. Akan tetapi dalam esai ini pembahasan akan dititikberatkan pada penggunaan force power untuk memberantas peredaran narkoba yang digunakan oleh kedua Negara.

Kedua konsep di atas merupakan sebuah kerangka konseptual yang integral yang saling berkaitan antara konsep force power dengan DMP. Hal ini dapat kita lihat dari hubungan dari kedua konsep tersebut, dimana force power merupakan salah satu output yang telah melalui proses formulasi kebijakan yang berasal dari berbagai macam input. Dengan demikian force power dapat dikatakan sebagai salah satu hasil atau luaran dari DMP itu sendiri.

Berikutnya peneliti menggunakan perumusan kebijakan publik dengan model system (Easton, dikutip dalam Winarno, 2008). Menurut model ini kebijakan publik dihasilkan dari sistem politik yang terdiri dari input kebijakan. Input dapat berupa support ataupun demand dari kebijakan yang akan diambil. Dalam sistem pemerintahan yang menganut asas demokrasi maka input di sini dapat diberikan oleh individu ataupun kelompok. Input kemudian diproses sehingga menghasilkan output yang merupakan suatu kebijakan publik. Kebijakan ini kemudian akan mendapatkan feedback dari publik, feedback ini kemudian dapat kembali menjadi bahan pertimbangan untuk input baik sebagai demand maupun support. Konsep perumusan kebijakan publik dengan model system ini dapat digambarkan dalam skema sebagai berikut: 
Tabel 3 Kerangka Kerja Sistem Menurut Easton

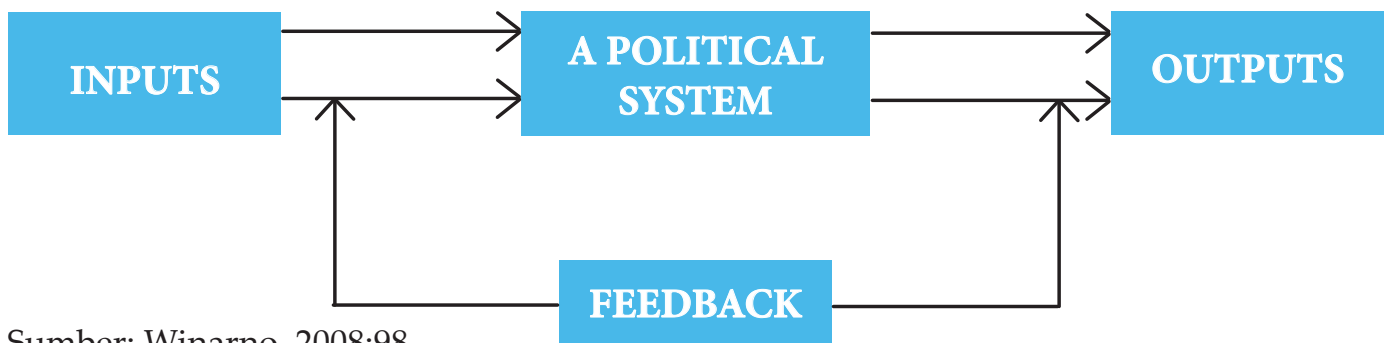

Sumber: Winarno, 2008:98

\section{Penggunaan Force Power}

Meksiko dan Indonesia sama-sama menggunakan force power dalam hal pemberantasan narkoba khususnya ketika berhadapan dengan kelompok kriminal dari masing-masing negara. Penggunaan force power ini seolah sudah menjadi suatu standar prosedur dalam penanganan peredaran narkoba. Tentu penggunaan force power memiliki implikasi tertentu seperti jatuhnya korban jiwa dan meningkatnya kekerasan terkait narkoba di negara tersebut.

Penggunaan instrumen force power dalam memberantas narkoba yang dilakukan oleh kedua negara memiliki cerita yang berbeda. Sejak awal perang melawan kartel narkoba dideklarasikan oleh Felipe Calderon pada tahun 2006, Meksiko melakukan perombakan besar-besaran pada personil aparatnya yaitu dengan memecat ribuan aparat kepolisian. Pada tahun 2010 Meksiko memecat 3.200 personil kepolisian yang kemudian disusul dengan 1.020 personil kepolisian yang juga dipecat (Olson, nbcnews 2010). Hal ini bertujuan untuk memperbaiki kinerja, kualitas, dan transparansi pemberantasan narkoba oleh Kepolisian Meksiko.

Selain itu, untuk memutus rantai perederan narkoba di Meksiko, pemerintah di sana menerapkan kebijakan ekstradisi tahanan. Ekstradisi tahanan telah dilakukan beberapa tahun sebelum Calderon menjabat. Ekstradisi bertujuan untuk melemahkan kekuatan kartel dengan memisahkan ketua ataupun para petinggi kartel menjauh dari daerah kekuasaannya. Dengan dijauhkannya para pemimpin kartel dari daerah kekuasaannya dan anggotanya diharapkan kartel tersebut mulai kehilangan arah ataupun terjadi perpecahan karena ditinggal sang pemimpin. Adapun para pemimpin kartel tersebut diekstradisi ke Amerika Serikat. Dengan begitu baik Meksiko dan Amerika Serikat dapat bekerja sama untuk melakukan investigasi mendalam terkait modus operandi yang digunakan oleh kartel tersebut dengan menginterogasi pimpinan kartel yang tertangkap. Kedua negara juga bisa mempelajari tentang letak markas dan kekuatan dari informasi yang diberikan pimpinan kartel. Dalam sebuah laporan yang disusun oleh U.S Senate Caucus on International Narcotics Control (2011) menunjukkan bahwa penangkapan terhadap pemimpin kartel setiap tahun mengalami peningkatan (Satria, 2012). 
Tabel 4 Ekstradisi Pempimpin Kartel Sejak 2000-2010

\begin{tabular}{|c|c|c|c|c|c|c|c|c|c|c|c|}
\hline Year & 2000 & 2001 & 2002 & 2003 & 2004 & 2005 & 2006 & 2007 & 2008 & 2009 & 2010 \\
\hline $\begin{array}{l}\text { Number of } \\
\text { Extraditions } \\
\text { from Mexico } \\
\text { to the United } \\
\text { States }\end{array}$ & 12 & 17 & 25 & 31 & 34 & 41 & 63 & 83 & 95 & 107 & 94 \\
\hline
\end{tabular}

Sumber: U.S Department of Justice, dikutip dari U.S and Mexican Response to Mexican Drug Trafficking Organizations, 2011:28.

Selain itu, pemerintah Meksiko juga menjalin kerja sama dengan beberapa negara lain sebagai salah satu implementasi penggunaan penggunaan force power yang ditujukan untuk memberantas narkoba di sana. Salah satu wujud kerja sama tersebut ialah Merida Initiative. Kerja sama tersebut sudah dimulai sejak pemerintahan George W. Bush dan masih terus berlanjut sampai pemerintahan Barrack Obama. Pada dasarnya Merida Initiative merupakan bantuan dana dalam jumlah besar kepada sejumlah negara di Amerika Tengah dan Meksiko, dimana Meksiko mendapatkan jatah bantuan paling besar. Dalam penerapannya ada banyak sekali bantuan yang diberikan oleh AS kepada Meksiko melalui kerja sama tersebut seperti transfer teknologi. Teknologi yang dimaksud misalnya alat yang dapat mendeteksi narkoba yang digunakan di wilayah perbatasan, bandara, maupun pelabuhan.

Selain itu, AS dan Meksiko juga bekerja sama untuk membatasi pergerakan kartel narkoba. Koordinasi yang baik antara aparat keamanan Meksiko dan penegak hukum di AS ditujukan untuk saling bertukar informasi mengenai musuh bersama yang sedang dihadapi. Disamping itu penambahan pasukan dalam jumlah yang besar dalam setiap operasi juga memberikan kemungkinan lebih besar untuk menangkap kartel dan membongkar pabrik pembuatan narkoba.

Bahkan, kerja sama tersebut berupaya untuk menghancurkan kekuatan kartel narkoba. Penambahan persenjataan yang mutakhir untuk menangkap atau membunuh anggota kartel dengan cara yang keras. Hal ini akan sangat membantu ketika aparat keamanan dipaksa untuk berperang melawan kartel baik di wilayah kota maupun pedesaan mengingat beberapa kartel narkoba sudah mempersenjatai diri mereka. Upaya kerja sama untuk memperkuat perbatasan juga dilakukan dengan penambahan jumlah pasukan patroli di wilayah 
perbatasan darat, pelabuhan, dan bandara. Hal ini penting mengingat kartel menyelundupkan narkoba ke AS melalui tiga jalur baik darat, udara, maupun laut.

Tabel 5 Pendanaan Merida Initiative

\begin{tabular}{|lllllll|l|l|l|} 
Account & $\begin{array}{l}2008 \\
\text { Supp } \\
\text { (\& 2009 } \\
\text { Bridge }\end{array}$ & $\begin{array}{l}2009 \\
\text { Omnibus }\end{array}$ & $\begin{array}{l}2009 \\
\text { Supp }\end{array}$ & $\begin{array}{l}2010 \\
\text { Omnibus }\end{array}$ & $\begin{array}{l}2010 \\
\text { Supp }\end{array}$ & Total & $\begin{array}{l}\text { FYI } \\
2011 \\
\text { Request }\end{array}$ & $\begin{array}{l}\text { FY } 2012 \\
\text { Request }\end{array}$ \\
\hline INCLE & $\$ 263.5$ & $\$ 246$ & $\$ 160$ & $\$ 190$ & $\$ 172$ & $\$ 1,034.5$ & $\$ 292$ & $\$ 248.5$ \\
\hline FMF & $\$ 116.5$ & $\$ 39$ & $\$ 260$ & $\$ 5.3$ & $\$ 0$ & $\$ 420.8$ & $\$ 8$ & Not Applicable \\
\hline ESF & $\$ 20$ & $\$ 15$ & $\$ 0$ & $\$ 15$ & $\$ 0$ & $\$ 50$ & $\$ 10$ & $\$ 33.3$ \\
\hline TOTAL & $\$ 400$ & $\$ 300$ & $\$ 420$ & $\$ 210.3$ & $\$ 175$ & $\$ 1,505.3$ & $\$ 310$ & $\$ 281.8$ \\
\hline
\end{tabular}

Sumber : Department of State, Office of Congressional Affairs, dikutip dari U.S and Mexican Response to Mexican Drug Trafficking Organizations, 2011:35.

Tabel 6 Merida Aviation Breakdown and Delivery Estimate

\begin{tabular}{|c|c|c|c|c|c|c|c|c|}
\hline & Account & Amount & Number & $\begin{array}{l}\text { Asset } \\
\text { Type }\end{array}$ & Recipient & Mission & $\begin{array}{l}\text { Procure- } \\
\text { ment Status }\end{array}$ & $\begin{array}{l}\text { Delivery } \\
\text { Date (est.) }\end{array}$ \\
\hline \multirow[t]{2}{*}{$\begin{array}{l}\text { FY } 2008 \\
\text { Supp. }\end{array}$} & $\begin{array}{l}\text { Foreign } \\
\text { Military } \\
\text { Financing } \\
\text { (FMF) }\end{array}$ & $\begin{array}{l}\$ 50 \text { mil- } \\
\text { lion }\end{array}$ & 1 & $\begin{array}{l}\text { CASA } \\
235\end{array}$ & $\begin{array}{l}\text { Secre- } \\
\text { tariat of } \\
\text { the Navy } \\
\text { (SEMAR) }\end{array}$ & $\begin{array}{l}\text { Maritime } \\
\text { Patrol Air } \\
\text { Aircraft }\end{array}$ & $\begin{array}{l}\text { Contract } \\
\text { awarded } \\
10 / 1 / 10\end{array}$ & $\begin{array}{l}\text { December } \\
2011\end{array}$ \\
\hline & $\begin{array}{l}\text { Foreign } \\
\text { Military } \\
\text { Financing } \\
\text { (FMF) }\end{array}$ & $\begin{array}{l}\$ 66 \text { mil- } \\
\text { lion }\end{array}$ & 5 & $\begin{array}{l}\text { Bell } \\
412\end{array}$ & $\begin{array}{l}\text { Secre- } \\
\text { tariat of } \\
\text { National } \\
\text { Defense } \\
\text { (SEDE- } \\
\text { NA) }\end{array}$ & $\begin{array}{l}\text { Mobility } \\
\text { Support/ } \\
\text { Interdic- } \\
\text { tion }\end{array}$ & $\begin{array}{l}\text { Contract } \\
\text { signed } \\
6 / 1 / 09\end{array}$ & $12 / 8 / 2009$ \\
\hline \multirow[t]{2}{*}{$\begin{array}{l}\text { FY } 2009 \\
\text { Omnibus }\end{array}$} & $\begin{array}{l}\text { Foreign } \\
\text { Military } \\
\text { Financing } \\
\text { (FMF) }\end{array}$ & $\begin{array}{l}\$ 39 \text { mil- } \\
\text { lion }\end{array}$ & 3 & $\begin{array}{l}\text { Bell } \\
412\end{array}$ & $\begin{array}{l}\text { Secre- } \\
\text { tariat of } \\
\text { National } \\
\text { Defense } \\
\text { (SEDE- } \\
\text { NA) }\end{array}$ & $\begin{array}{l}\text { Mobility } \\
\text { Support/ } \\
\text { Interdic- } \\
\text { tion }\end{array}$ & $\begin{array}{l}\text { Contract } \\
\text { awarded } \\
2 \text { Bells on } \\
4 / 30 / 10 \text {; } \\
\text { contract } \\
\text { modified } \\
\text { 9/8/10 for } 1 \\
\text { Bell }\end{array}$ & $\begin{array}{l}\text { Deliveries } \\
\text { completed } \\
12 / 10 \\
(2 \text { on } \\
11 / 8 / 10 \\
\text { and } 1 \text { on } \\
12 / 17 / 10)\end{array}$ \\
\hline & $\begin{array}{l}\text { Interna- } \\
\text { tional } \\
\text { Narcotics } \\
\text { Control } \\
\text { and Law } \\
\text { Enforce- } \\
\text { ment } \\
\text { (INCLE) }\end{array}$ & $\begin{array}{l}\$ 15.5 \\
\text { million }\end{array}$ & 1 & $\begin{array}{l}\text { Dorn- } \\
\text { ier } 328 \\
\text { Jet }\end{array}$ & $\begin{array}{l}\text { Secer- } \\
\text { tariat of } \\
\text { Public } \\
\text { Security } \\
\text { (SSP) }\end{array}$ & $\begin{array}{l}\text { Intelli- } \\
\text { gence, Sur- } \\
\text { veillance, } \\
\text { and Recon- } \\
\text { naisance } \\
\text { (ISR) }\end{array}$ & $\begin{array}{l}\text { Platform } \\
\text { \& ISR } \\
\text { configura- } \\
\text { tion under } \\
\text { review }\end{array}$ & $\begin{array}{l}\text { Target } \\
\text { comple- } \\
\text { tion date } \\
12 / 31 / 11\end{array}$ \\
\hline
\end{tabular}




\begin{tabular}{|c|c|c|c|c|c|c|c|c|}
\hline \multirow[t]{4}{*}{$\begin{array}{l}\text { FY } 2009 \\
\text { Supp. }\end{array}$} & $\begin{array}{l}\text { Interna- } \\
\text { tional } \\
\text { Narcotics } \\
\text { Control } \\
\text { and Law } \\
\text { Enforce- } \\
\text { ment } \\
\text { (INCLE) }\end{array}$ & $\begin{array}{l}\$ 76.5 \\
\text { million }\end{array}$ & 3 & $\begin{array}{l}\mathrm{UH}- \\
60 \mathrm{M}\end{array}$ & $\begin{array}{l}\text { Secer- } \\
\text { tariat of } \\
\text { Public } \\
\text { Security } \\
\text { (SSP) }\end{array}$ & $\begin{array}{l}\text { Mobility } \\
\text { Support }\end{array}$ & $\begin{array}{l}\text { Helicopters } \\
\text { were manu- } \\
\text { factured by } \\
1 / 2010\end{array}$ & $\begin{array}{l}\text { Delivered } \\
11 / 12 / 10\end{array}$ \\
\hline & $\begin{array}{l}\text { Foreign } \\
\text { Military } \\
\text { Financing } \\
\text { (FMF) } \\
\end{array}$ & $\begin{array}{l}\$ 150 \\
\text { million }\end{array}$ & 3 & $\begin{array}{l}\text { CASA } \\
235\end{array}$ & $\begin{array}{l}\text { Secre- } \\
\text { tariat of } \\
\text { the Navy } \\
\text { (SEMAR) }\end{array}$ & & $\begin{array}{l}\text { Contract } \\
\text { awarded } \\
10 / 1 / 10\end{array}$ & $\begin{array}{l}\text { February } \\
\text { - April } \\
2012\end{array}$ \\
\hline & $\begin{array}{l}\text { Interna- } \\
\text { tional } \\
\text { Narcotics } \\
\text { Control } \\
\text { and Law } \\
\text { Enforce- } \\
\text { ment } \\
\text { (INCLE) }\end{array}$ & $\begin{array}{l}\$ 83.5 \\
\text { million }\end{array}$ & 3 & $\begin{array}{l}\mathrm{UH}- \\
60 \mathrm{M}\end{array}$ & $\begin{array}{l}\text { Secer- } \\
\text { tariat of } \\
\text { Public } \\
\text { Security } \\
\text { (SSP) }\end{array}$ & $\begin{array}{l}\text { Mobility } \\
\text { Support }\end{array}$ & $\begin{array}{l}\text { Helicopters } \\
\text { on manu- } \\
\text { facture con- } \\
\text { tract with } \\
\text { AMCOM }\end{array}$ & $\begin{array}{l}\text { Expert } \\
\text { delivery } \\
\text { (fully } \\
\text { modifed } \\
\text { to GOM } \\
\text { specs) (1) } \\
\text { Nov } 2011 \\
\text { (2) Feb } \\
2012\end{array}$ \\
\hline & $\begin{array}{l}\text { Foreign } \\
\text { Military } \\
\text { Financing } \\
\text { (FMF) }\end{array}$ & $\begin{array}{l}\$ 110 \\
\text { million }\end{array}$ & 3 & $\begin{array}{l}\text { UH- } \\
60 \mathrm{M}\end{array}$ & $\begin{array}{l}\text { Secre- } \\
\text { tariat of } \\
\text { the Navy } \\
\text { (SEMAR) }\end{array}$ & $\begin{array}{l}\text { Support } \\
\text { Maritime } \\
\text { Interdic- } \\
\text { tion and } \\
\text { Security } \\
\text { Operations }\end{array}$ & $\begin{array}{l}\text { Contract } \\
\text { awarded } \\
9 / 7 / 10\end{array}$ & $\begin{array}{l}\text { Septem- } \\
\text { ber } 2011\end{array}$ \\
\hline
\end{tabular}

Sumber: Department of State, Office of Congressional Affairs, dikutip dari U.S and Mexican Response to Mexican Drug Trafficking Organizations, 2011:35

Berbeda dengan Meksiko yang begitu kentara penggunaan force power, terutama penggunaan senjata bahkan militer, force power yang digunakan Indonesia lebih mengarah pada judiciary power atau power berdasarkan hukum yakni penekanan pemberian ganjaran hukuman yang seberat-beratnya pada bandar dan pengedar narkoba. Upaya pemberantasan narkoba dengan force power ini lebih kentara pada masa kepemimpinan Presiden Joko Widodo dibandingkan dengan dengan masa Susilo Bambang Yudhoyono.

Upaya pemberantasan narkoba secara yang dilakukan oleh Indonesia ini dikarenakan oleh adanya perubahan paradigma Indonesia mengenai kejahatan narkoba. Pemerintah Indonesia saat ini memandang bahwa status dan kondisi saat ini dalam bahaya besar yang diakibatkan oleh narkoba. Pemerintah Indonesia memandang bahwa Indonesia dalam kondisi darurat narkoba nasional, sehingga pemberantasan narkoba menjadi salah satu agenda prioritas nasional Indonesia (Supermana, 2015). Penerapan kebijakan ini didasari oleh pandangan bahwa terdapat sekitar 50 orang Indonesia meregang nyawa setiap hari akibat narkoba. Pemerintah Indonesia menganggap korbankorban yang berjatuhan tersebut merupakan kesalahan dan tanggung jawab dari para pengedar narkoba. Oleh karena itu, pemerintahan Indonesia menerapkan hukuman keras pada para bandar narkoba yakni sampai dengan hukuman eksekusi mati dengan cara ditembak. 
Tercatat sejak awal pemerintahan sampai saat ini, Indonesia di bawah kepemimpinan Jokowi, sudah ada belasan terpidana kasus narkoba yang dieksekusi mati dan 64 terpidana lainnya sedang dalam masa tunggu menuju eksekusi. Para terpidana tadi terdiri dari 25 WNI dan sisanya adalah WNA yang berasal dari Nigeria, Australia, Vietnam, Malaysia, Brazil, Belanda, dan beberapa negara lainnya (Hukum Online, 2015).

Selain menggunakan judiaciary power sebagai salah satu wujud force power, Indonesia juga melakukan upaya force power lainnya yakni dengan cara memperkuat Badan Narkotika Nasional (BNN). Kebijakan memperkuat $\mathrm{BNN}$ ini diambil oleh pemerintah Indonesia karena BNN merupakan garda terdepan dalam memberantas, memerangi, dan menanggulangi penyebaran narkoba di Indonesia. Status Indonesia yang dalam kondisi darurat narkoba tentunya semakin mendorong adanya keinginan kuat untuk memerangi peredaran narkoba itu sendiri, salah satu caranya ialah memperkuat BNN yang selama ini berperan menjalankan tugas tersebut (Lamanauw, 2015). Usaha untuk memperkuat kelembagaan BNN ini dilakukan dengan berbagai cara. Pemerintah Indonesia sudah menambah anggaran operasional BNN, perbaikan teknologi, dan menaikkan kesejahteraan pegawai BNN. Selain itu di pihak lain, legislatif Indonesia juga turut membantu upaya memperkuat kelembagaan BNN dengan menyiapkan rancangan undang-undang (RUU) Narkotika yang nantinya akan menyokong usaha memerangi dan memberantas peredaran narkoba (Marboen, 2016). Upaya serius Pemerintah Indonesia dalam pemberantasan narkoba juga diwujudkan dengan menaikkan status BNN menjadi setingkat kementrian. Kebijakan menaikkan status ini tidak hanya ditujukan untuk memperkuat kelembagaan BNN namun juga memperluas otoritas BNN dalam menjalankan tugasnya untuk memerangi, memberantas, dan menanggulangi penyebaran narkoba (Hermawan, 2016).

\section{Peredaran Narkoba: Indonesia Target Pasar, Meksiko Jalur Distribusi Narkoba}

Indonesia dan Meksiko sama-sama menghadapi peliknya permasalahan tentang peredaran narkoba yang ada di negara masing-masing. Kedua negara sama-sama kesulitan untuk memutus siklus permintaan dan penawaran yang terjadi. Sedangkan perbedaannya adalah Indonesia dijadikan sebagai target pasar oleh para produsen dan distributor narkoba di level internasional karena potensi pasar yang besar. Untuk itu Indonesia harus menjaga teritorialnya dengan baik agar penyelundupan narkoba dari pasar internasional dapat dicegah. Jalur penyelundupan narkoba yang potensial seperti melalui bandara dan pelabuhan menjadi target pengawasan dari pemerintah Indonesia. Hanya saja luas lautan Indonesia tidak berbanding dengan jumlah aparat keamanan yang mampu menjaga seluruh perbatasan khususnya wilayah perairan sehingga sangat mungkin untuk ditembus oleh penyelundup narkoba. Untuk penyelundupan melalui jalur darat sangat jarang mengingat Indonesia 
berbatasan dengan Negara seperti Papua Nugini, Malaysia, dan Timor -Leste. Wilayah perbatasan darat dengan negara-negara tersebut pun sulit untuk ditempuh menggunakan jalur darat.

\section{Grafik 1 Nilai peredaran kokain di Amerika Utara 2008}

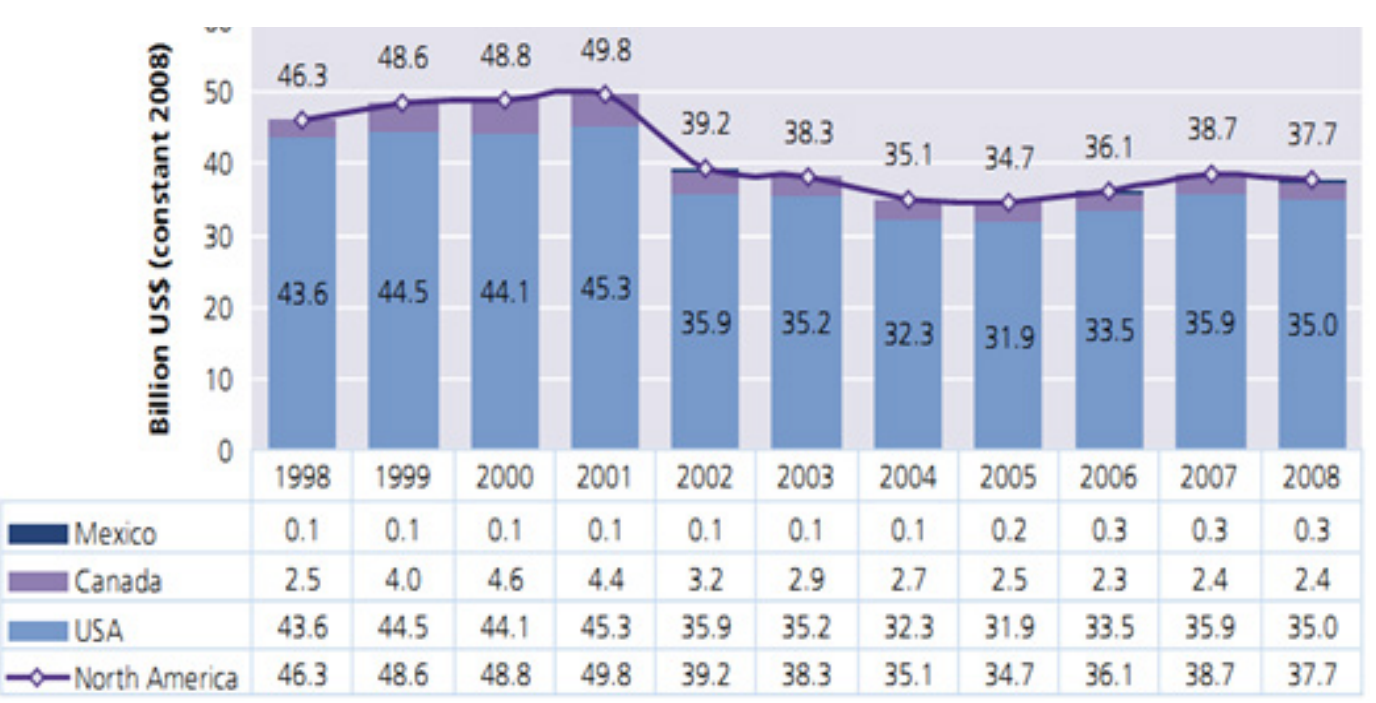

Sumber: World Drug Report, 2010:78

\section{Gambar 1 Peredaran kokain global 2008}

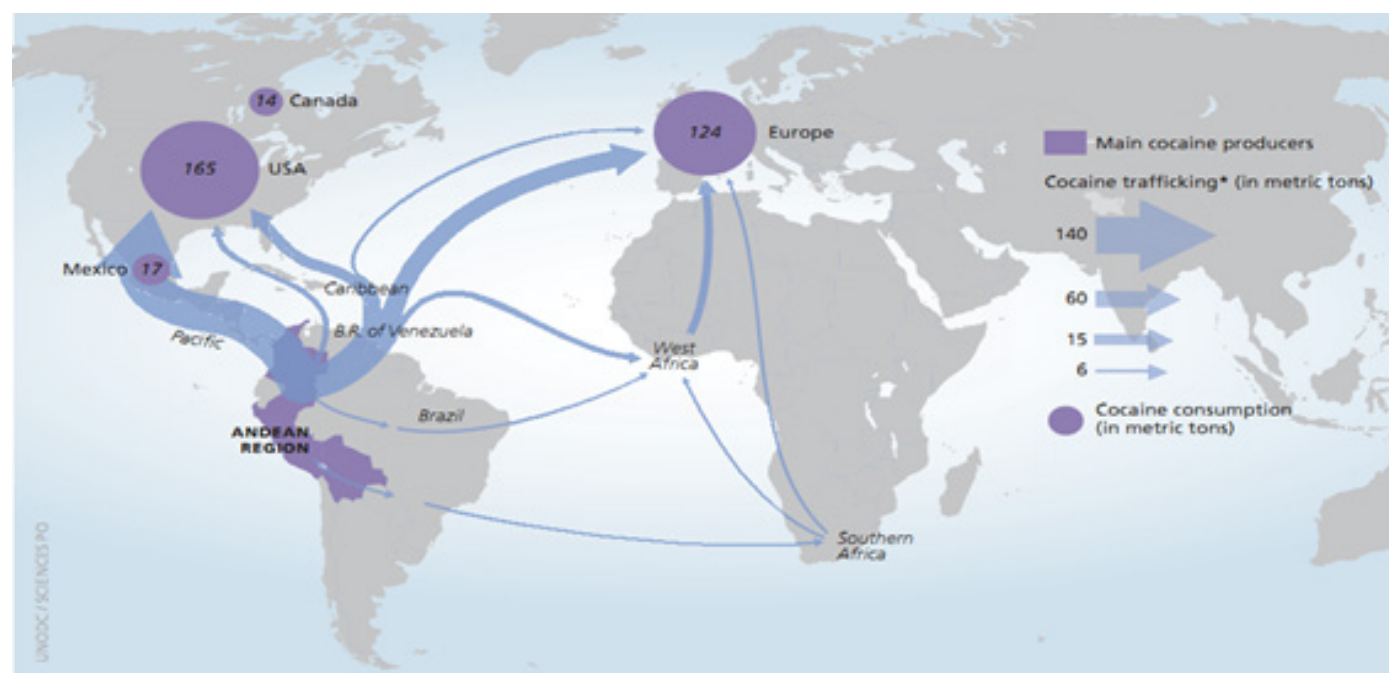

Sumber: World Drug Report, 2010:70

Sedangkan dalam kasus Meksiko, peredaran narkoba yang ada di Meksiko bukan merupakan pasar utama, melainkan tempat produksi dan distribusi dari narkoba. Narkoba yang diproduksi di Meksiko 
kemudian didistribusikan ke pasar utamanya yaitu Amerika Serikat. Proses distribusinya berbeda dengan Indonesia, di Meksiko narkoba didistribusikan dengan cara diselundupkan melalui terowongan bawah tanah yang lebih sulit untuk dideteksi. Hal ini tidak terlepas dari panjangnya garis perbatasan darat antara Meksiko dan AS. Oleh karena itu, Meksiko dan AS berbagi tanggung jawab untuk mengawasi wilayah perbatasan darat kedua negara yang membentang panjang.

\section{Eskalasi Kekerasan di Meksiko dan Lesson Learned untuk Indonesia}

Di Meksiko semakin besar power yang digunakan untuk membasmi kartel maka akan semakin tinggi pula eskalasi kekerasan yang terjadi selama penggunaan power tersebut. Di samping itu, kartel sendiri memiliki kemampuanuntukmenyerangbalikaparatkeamanan dengan menggunakan power yang mampu mengimbangi kekuatan tempur lawannya itu. Kondisi ini menyebabkan spiral kekerasan di Meksiko semakin membesar. Hal ini dikarenakan setiap serangan yang dilancarkan pemerintah selalu dibalas oleh kartel dengan menggunakan kekerasan pula. Semakin kuat serangan dan tekanan yang diberikan pemerintah maka kartel akan melancarkan reaksi berupa serangan yang kuat pula. Dalam kondisi spiral kekerasan yang tidak berujung ini sulit rasanya mencegah eskalasi kekerasan di Meksiko (Satria, 2012).

Kemampuan kartel di Meksiko dalam menghadapi kebijakan represif pemerintah merupakan permasalahan yang muncul karena dua hal. Pertama, kartel di Meksiko memiliki memiliki persenjataan dan strategi sebagai perlindungan. Menurut Mulyadi (2012) kartel bahkan memiliki pabrik pembuatan seragam militer. Dengan menggunakan seragam tersebut kartel mampu mengelabui aparat keamanan bahkan dapat melakukan operasi di jalanan untuk membunuh ataupun menculik orang-orang yang menjadi musuh mereka. Kartel juga memiliki persenjataan yang dibeli melalui eksploitasi hukum di AS yang melegalkan perdagangan senjata. Kartel melalui kurirnya yang berada di AS membeli senapan dari toko-toko senjata melalui kurir tersebut. Menurut Isakoff (2011) Kepolisian Negara Bagian Arizona menangkap 20 orang yang membeli ratusan AK-47 dan senjata api jenis lainnya dari toko-toko senjata di AS. Mereka memborong persediaan senjata AK-47 yang ada di toko tersebut dan mengirimnya ke anggota kartel yang berada di Meksiko untuk mempersenjatai diri. 


\section{Gambar 2 Peta Kekuatan Kartel Meksiko dan Pengaruhnya}

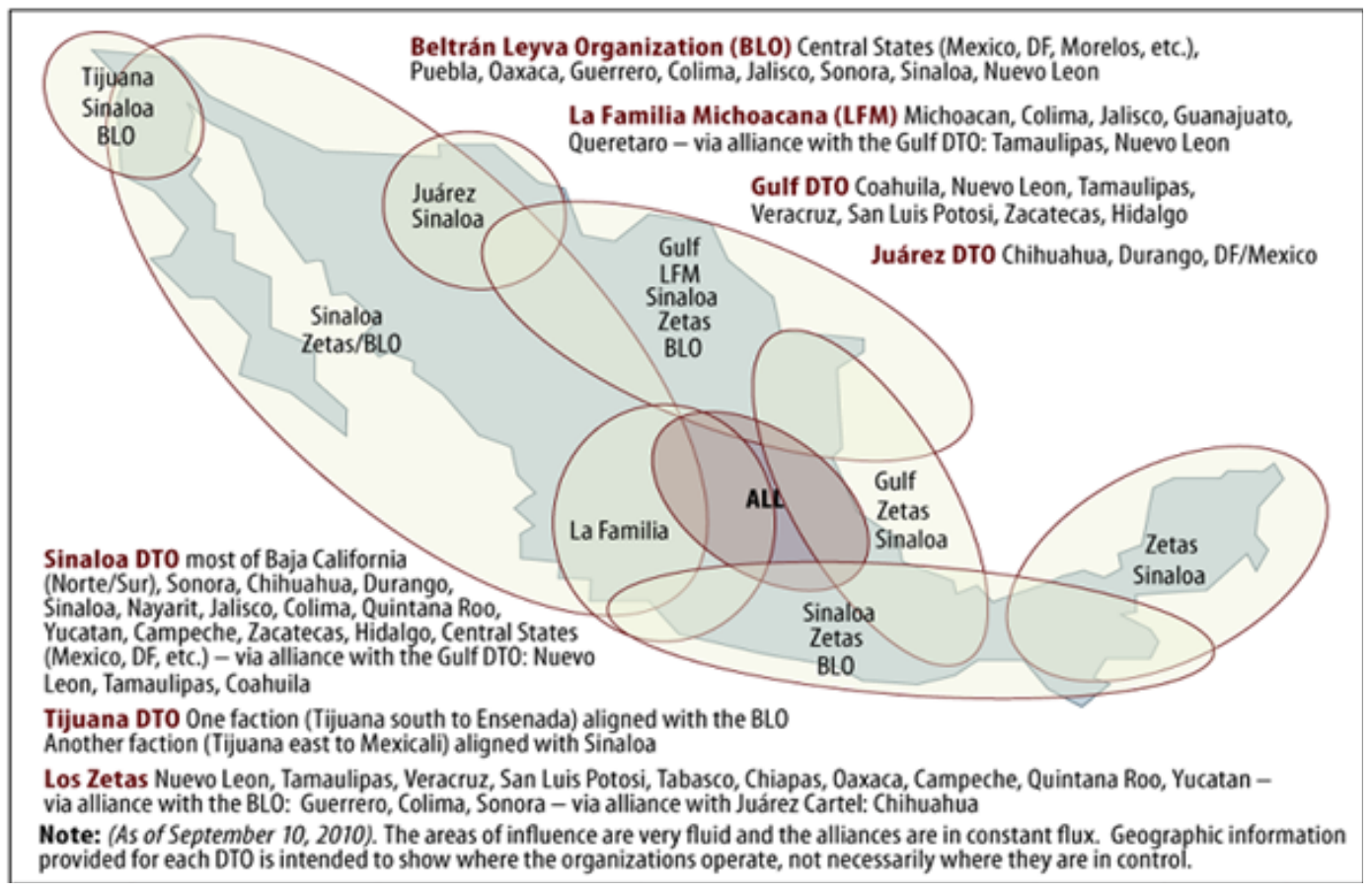

Sumber: U.S and Mexican Response to Mexican Drug Trafficking Organizations, 2011.

Kedua, kartel memiliki sumber pendanaan yang sangat besar. Dana kartel mayoritas merupakan dana yang dihasilkan dari penjualan narkoba. Selain itu ada pula kemungkinan kartel mendapatkan dana tambahan dari menculik dan memeras korban, serta sumber dana lainnya. Peredaran narkoba memiliki keuntungan yang luar biasa besar. Dengan menggeluti bidang ini selama puluhan tahun, menjadikan setiap kartel memiliki persediaan dana dalam jumlah yang cukup besar. Hal ini memungkinkan mereka beroperasi tanpa harus mengharapkan bantuan dari luar. Berbeda dengan pemberontak Libya yang harus mendapatkan sokongan dana dan senjata dari pihak ketiga, kartel narkoba Meksiko mencari dana sendiri dan mempersenjatai diri mereka sendiri sehingga sulit bagi AS dan Meksiko untuk memerangi kartel. Meski pemerintah AS dan Meksiko sudah berupaya habis-habisan untuk memotong supply narkoba tetapi tampaknya hal tersebut tidak mengurangi kekuatan kartel. Permintaan akan narkoba di AS sendiri masih cukup tinggi dan harga narkoba di pasar AS juga masih cenderung stabil yang menunjukkan belum ada kelangkaan supply dari Meksiko ke pasar.

Willingness dari pemerintah Meksiko untuk memberantas narkoba dan penggunaan force power sebagai instrumen utamanya tentu berdampak pada stabilitas keamanan yang ada di Meksiko. Kemampuan kartel narkoba 
untuk melakukan perlawanan juga berkontribusi terhadap eskalasi kekerasan yang terjadi di Meksiko. Sejak diberlakukannya kebijakan perang melawan narkoba di Meksiko pada tahun 2006, tercatat terjadi peningkatan kekerasan dalam beberapa tahun implementasi kebijakan tersebut. Hal tersebut diperkuat dengan bukti pada Tabel 7 di bawah ini:

Tabel 7 Meningkatnya Kekerasan di Beberapa Negara Bagian Meksiko

\begin{tabular}{|l|l|l|l|l|l|}
\hline \multicolumn{1}{|c|}{ State } & \multicolumn{1}{|c|}{$\mathbf{2 0 0 7}$} & \multicolumn{1}{c|}{$\mathbf{2 0 0 8}$} & \multicolumn{1}{c|}{$\mathbf{2 0 0 9}$} & \multicolumn{1}{c|}{$\mathbf{2 0 1 0}$} & $\begin{array}{c}\text { Total } \\
\text { Homicides }\end{array}$ \\
\hline Chihuahua & 148 & 1649 & 2028 & 4427 & 8306 \\
\hline Sinaloa & 346 & 680 & 767 & 1815 & 3608 \\
\hline Guerrero & 253 & 287 & 638 & 1137 & 2315 \\
\hline Durango & 130 & 268 & 637 & 834 & 1869 \\
\hline Tamaulipas & 89 & 110 & 49 & 1209 & 1457 \\
\hline Nuevo Leon & 107 & 78 & 99 & 620 & 904 \\
\hline Jalisco & 93 & 145 & 212 & 593 & 1043 \\
\hline Mexico State & 111 & 359 & 354 & 623 & 1447 \\
\hline Baja California & 154 & 604 & 320 & 540 & 1618 \\
\hline Michoacan & 238 & 233 & 371 & 520 & 1362 \\
\hline
\end{tabular}

Sumber: The Trans-Border Institute, dikutip dari U.S and Mexican Response to Mexican Drug Trafficking Organizations, 2011:18.

Data di atas bisa menjadi cerminan output dari kebijakan perang melawan narkoba dengan menggunakan force power yang dilakukan oleh Meksiko. Sedangkan Indonesia memiliki tantangan yang berbeda. Di Indonesia para bandar narkoba atau kartel kecil di Indonesia tidak terlihat mampu mengimbangi force power yang digunakan oleh pemerintah Indonesia. Perlawanan sengit terhadap aparat pemberantas narkoba ketika melakukan penggerebekan hampir tidak pernah terlihat. Hal ini tentu saja tidak berpengaruh terhadap rendahnya tingkat korban yang jatuh pada agenda pemberantasan narkoba.

Walapun demikian, perlawanan para bandar narkoba terhadap judiciary power pada masa sebelum Presiden Jokowi menjabat dapat diasumsikan sangat kentara. Kerja sama antara pengedar narkoba dengan aparat penegak hukum sudah menjadi sesuatu hal yang dianggap lumrah, sulit dibuktikan secara hukum tetapi dapat dirasakan secara faktual. Hal ini dapat dilihat dari banyaknya usaha penggerebekan yang banyak menemui kegagalan karena para bandar sudah melarikan diri terlebih dahulu sebelum berhasil digerebek. Para bandar yang lari tersebut ditengarai karena para bandar tersebut sudah mendapatkan informasi akan adanya penggerebekan 
dari informan mereka yang berada di tubuh aparat penegak hukum, dengan imbalan para bandar tersebut akan memberikan setoran rutin kepada mereka. Selain itu, bandar yang sudah tertangkap juga kerapkali dapat membeli berbagai macam fasilitas di dalam tahanan. Mereka dapat membeli ruangan yang nyaman, memasukkan berbagai macam alat dan teknologi, bahkan mereka juga dapat dengan mudah memasukkan wanita. Dengan alat dan teknologi yang mereka miliki dalam penjara, tidak heran apabila mereka tetap dapat mengendalikan peredaran narkoba dari dalam sel tahanan. Hal ini diperkuat dengan adanya beberapa kasus para sipir penjara yang tertangkap menjadi kurir bahkan bandar narkoba.

Walaupun perlawanan terhadap agenda pemberantasan narkoba tidak sekuat di Meksiko, pada awal tahun 2016 di Indonesia terjadi insiden yang banyak disebut sebagai miniatur perlawanan kartel narkoba. Saat itu, 18 Januari 2016, empat anggota Direktorat Reserse Narkoba Kepolisian Sektor Senen dan dua orang informan melakukan penggerebekan terhadap bandar narkoba di Jalan Slamet Riyadi IV Matraman, Jakarta Timur. Pada saat penggerebekan tersebut, warga sekitar yang juga anak buah dari bandar yang hendak ditangkap menyerang para polisi dengan menggunakan berbagai macam senjata tajam Keempat anggota polisi yang terluka tersebut menceburkan diri ke Kali Manggarai untuk menyelamatkan diri. Tiga di antaranya selamat, tetapi Bripka Taufik menghilang bersama dengan seorang informan polisi dan beberapa saat kemudian ditemukan dalam kondisi telah meninggal (Inge, 2016). Insiden ini direspon dengan cepat oleh pihak Kepolisian. Kepolisian dapat menangkap bandar narkoba beserta para pelaku penyerangan petugas polisi tersebut dengan cepat.

Adapun lesson learned yang dapat diambil dari kasus Meksiko untuk Indonesia antara lain: pertama, Indonesia harus menjaga agar kartel tidak memiliki senjata baik yang diselundupkan maupun yang dirakit di dalam negeri. Selama kartel di Indonesia tidak memiliki senjata, maka kemampuan membalas atau melakukan perlawanan terhadap force power yang dikerahkan oleh pemerintah dapat diminimilisasi; kedua, kondisi lemahnya kartel harusnya dapat digunakan oleh pemerintah Indonesia untuk memberantas narkoba dengan menggunakan elemen terror dari force power. Namun, perlu diperhatikan bahwasanya penggunaan force power yang berlebihan dapat meningkatkan kemungkinan terjadinya pelanggaran HAM. Untuk itu perlu diperhatikan standard operating procedure (SOP) yang dimiliki kepolisian dalam pemberantasan narkoba

\section{Feedback Masyarakat terhadap Kebijakan Pemerintah}

Masyarakat Meksiko terbelah menjadi dua kelompok besar dalam menanggapi kebijakan pemerintahnya untuk memerangi narkoba. Kelompok yang pertama ialah kelompok yang mendukung kebijakan pemerintah dalam memerangi kartel narkoba. Kelompok ini berargumen bahwa keberadaan 
kartel narkoba yang telah ada selama puluhan tahun merupakan faktor utama yang menyebabkan tingginya tingkat pembunuhan dan kriminalitas di Meksiko. Kartel narkoba dianggap sebagai faktor utama penyebab bencana rusaknya mentalitas rakyat Meksiko yang dahulunya adalah penganut agama Katolik taat. Kartel narkoba dipandang sebagai faktor utama penyebab distabilitas keamanan di Meksiko. Akibat adanya kartel narkoba tersebut, para investor dan turis asing takut masuk ke Meksiko karena khawatir akan menjadi korban dari kartel narkoba tersebut. Selain itu kelompok ini juga menolak dengan keras alasan para kartel narkoba dan pendukungnya bahwa kemunculan mereka untuk memberikan kesejahteraan ekonomi dan sosial kepada rakyat meksiko. Mereka berargumen bahwa setelah puluhan tahun keberadaan kartel narkoba di Meksiko, keadaan rakyat Meksiko tetap saja dalam kondisi kemiskinan (Latimes, 2015).

Kelompok kedua yang cukup kuat di Meksiko adalah kelompok yang mendukung keberadaan kartel narkoba. Kelompok ini cenderung menyalahkan ketidakmampuan pemerintah Meksiko dalam mengelola negara. Mereka menganggap bahwa pemerintah Meksiko telah gagal memberikan kesejahteraan bagi rakyat Meksiko. Kebijakan-kebijakan pemerintah Meksiko dinilai oleh mereka telah gagal mengentaskan kemiskinan. Di lain sisi, mereka memandang bahwa kartel narkoba datang membawa harapan. Kartel narkoba dianggap sebagai pihak yang mampu menyediakan kesejahteraan bagi mereka. Kelompok ini sangat mengapresiasi kartel narkoba yang mampu menyediakan lapangan pekerjaan, sekolah, dan fasilitas kesehatan bagi rakyat Meksiko (Gordon, 2015). Dengan kuatnya keberadaan kelompok kedua ini maka tidak mengherankan apabila cukup banyak rakyat Meksiko yang mendukung bahkan bergabung dengan kartel narkoba. Hal ini tentu saja berimbas pada sulitnya pemberantasan peredaran narkoba di negara tersebut.

Di Indonesia, sebagian besar komponen masyarakatnya mendukung kebijakan pemerintah dalam memberantas peredaran narkoba. Berbagai macam golongan seperti penegak hukum, cendekiawan, musisi, mahasiswa, pemerintah daerah, lembaga swadaya masyarakat, dan organisasi keagamaan mengecam peredaran narkoba di Indonesia. Mereka yakin bahwa peredaran narkoba hanya akan membawa dampak buruk bagi Indonesia dan rakyatnya. Narkoba dianggap sebagai faktor utama penyebab rusaknya moral dan generasi muda penerus bangsa. Oleh karena itu, mereka selalu mendukung kebijakan tegas pemerintah terhadap bandar dan pengedar narkoba. Mereka juga memberikan dukungan kepada pemerintah Indonesia dalam penerapan hukuman mati terhadap narapidana kriminal narkoba di Indonesia, baik untuk WNI maupun WNA.

Namun, ada beberapa kelompok kecil masyarakat Indonesia yang menolak penerapan hukuman mati bagi terpidana kasus narkoba. Sebagian besar dari mereka yang menolak penerapan hukuman mati tersebut 
ialah para pejuang HAM. Salah satu pihak yang sangat terlihat menolak penerapan hukuman mati tersebut ialah Koalisi Masyarakat Sipil (KMS). KMS sendiri terdiri dari gabungan beberapa LSM pejuang HAM seperti ELSAM, Imparsial, ICJR, IKOHI, ILRC, LBH Masyarakat, Migrant Care, Yayasan Satu Keadilan, LBH Jakarta, dan PBHI. Koalisi Masyarakat Sipil yang menolak hukuman mati mendorong tiga tuntutan kepada pemerintah, pertama menghentikan rencana eksekusi terhadap 10 terpidana mati pada akhir April 2015. Mendorong sistem pemidanaan yang lebih sesuai dengan prinsip-prinsip hak asasi manusia (HAM). Kedua, mereka meminta agar pemerintah membenahi sistem peradilan dan pemenjaraan di Indonesia yang diduga sarat dengan praktik korupsi dan suap. Ketiga, meratifikasi Protokol Opsional Hak Sipil dan Politik tentang Penghapusan Hukuman Mati (Taufiqurrohman, 2015).

\section{Kesimpulan}

Kasus yang dihadapi oleh Meksiko dan Indonesia pada dasarnya sama. Tetapi jika dikaji lebih dalam terdapat beberapa perbedaan yang mencolok. Studi perbandingan mencoba melihat apa saja perbedaan yang mendasar dari sudut pandang akademis terkait kedua negara tersebut dengan tujuan untuk memberikan parameter yang jelas kepada para pemangku kekuasaan dalam mengambil keputusan politiknya.

Pertama, kedua negara sama-sama memiliki willingness untuk memerangi narkoba dan hal tersebut diwujudkan melalui pernyataan untuk memerangi narkoba. Hal ini telah menjadi komitmen masing-masing Kepala Pemerintahan yaitu Meksiko pada masa Presiden Felipe Calderon dan Indonesia pada masa Presiden Joko Widodo. Sedangkan perbedaannya adalah Indonesia dijadikan sebagai target pasar oleh para produsen dan distributor narkoba di level internasional karena potensi pasar yang besar. Oleh karena itu, Indonesia harus menjaga teritorialnya dengan baik agar penyelundupan narkoba dari internasional dapat dicegah. Jalur penyelundupan narkoba yang potensial seperti melalui bandara dan pelabuhan menjadi target pengawasan dari pemerintah Indonesia. Namun, luas lautan Indonesia tidak berbanding dengan jumlah aparat keamanan yang mampu menjaga seluruh perbatasan khususnya wilayah perairan, sehingga sangat mungkin untuk ditembus oleh penyelundup narkoba. Untuk penyelundupan melalui jalur darat sangat jarang mengingat Indonesia berbatasan dengan negara seperti Papua Nugini, Malaysia, dan Timor-Leste. Wilayah perbatasan darat dengan negara-negara tersebut pun sulit untuk ditempuh menggunakan jalur darat. Sedangkan dalam kasus Meksiko, peredaran narkoba yang ada di Meksiko bukan merupakan pasar utama, melainkan tempat produksi dan distribusi dari narkoba. Narkoba yang diproduksi di Meksiko kemudian didistribusikan ke pasar utamanya yaitu AS. Proses distribusinya berbeda dengan Indonesia, di Meksiko narkoba didistribusikan dengan cara diselundupkan melalui 
terowongan bawah tanah yang notabene lebih sulit untuk dideteksi. Hal ini tidak terlepas dari panjangnya garis perbatasan darat antara Meksiko dan AS. Untuk itu Meksiko dan AS berbagi tanggung jawab untuk mengawasi wilayah perbatasan darat kedua Negara yang membentang panjang.

Kedua, pemerintah Meksiko mengutamakan force power dalam pemberantasan narkoba yang ada di negaranya. Hal ini disebabkan oleh kemampuan dari para kartel narkoba di Meksiko yang mampu mengimbangi aparat keamanan Meksiko dengan persenjataan yang mereka miliki. Persenjataan yang dimiliki kartel narkoba Meksiko dibeli di AS dengan cara eksploitasi terhadap hukum legalitas perdagangan senjata di AS. Senjata tersebut kemudian diselundupkan melalui terowongan bawah tanah menuju Meksiko dimana terowongan yang sama juga digunakan untuk menyelundupkan narkoba menuju AS. Hal berbeda terjadi dalam kasus Indonesia misalnya yang tidak serta-merta mengedepankan force power karena kartel narkoba yang ada di Indonesia tidak seberbahaya kartel narkoba di Meksiko. Kartel narkoba di Indonesia tidak memiliki persenjataan dalam skala besar sehingga pemerintah Indonesia tidak membutuhkan pendekatan force power dalam porsi yang berlebihan seperti yang dilakukan oleh pemerintah Meksiko. Hal ini dikarenakan tidak ada negara di sekitar Indonesia yang memberlakukan hukum legalitas terhadap jual beli senjata di negaranya. Selain itu kemampuan aparat penegak keamanan Indonesia jauh di atas kemampuan kartel narkoba yang ada di Indonesia sehingga tidak mungkin kartel narkoba yang ada di Indonesia melakukan perlawanan khususnya dengan menggunakan senjata.

Ketiga, output dari kebijakan pemberantasan narkoba di Meksiko adalah meningkatnya kekerasan dan tentu memperburuk stabilitas keamanan domestik yang ada di negara tersebut. Hal ini masih terus berlanjut sejak diberlakukannya perang melawan narkoba di Meksiko pada tahun 2006 oleh Calderon. Jumlah korban pun tentunya semakin bertambah karena sejauh ini belum ada tanda-tanda akan berhenti. Sedangkan dalam kasus Indonesia, hendaknya kondisi kartel yang lemah dimanfaatkan dengan baik dan tepat. Kepolisian harus mampu menindak dengan cepat dan efektif tanpa mengerahkan terlalu banyak elemen dari force power yang dikhawatirkan dapat menyebabkan pelanggaran HAM dan SOP dalam implementasinya.

\section{Daftar Pustaka}

Anckar, C. (2011). On the Applicability of the Most Similar Systems Design and the Most Different Systems Design in Comparative Research. International Journal of Social Research Methodology 11(5) 389-401

Gordon, R. (2015). The Failed War on Drugs in Mexico (and the United States). (online). Tersedia dalam: <http://billmoyers.com/2015/03/27/ can-say-blowback-spanish/> [diakses 3 April 2016] 
Hansson, S. (2009) Decision Theory: A Brief Introduction. Royal Institute of Technology, Stockholm

Hermawan, B. (2016). Luhut: Presiden Bertekad Naikan Status BNN Jadi Setingkat Menteri, (online). Rapublika online. Tersedia dalam: $<$ http://www.republika.co.id/berita/nasional/hukum/16/03/10/ o3tigk354-luhut-presiden-bertekad-naikan-status-bnn-jadisetingkat-menteri> [diakses 3 April 2016]

HukumOnline (2015). Ini Daftar Nama 64 Terpidana Mati Narkotika, (online). Tersedia dalam: http://www.hukumonline.com/berita/ baca/lt54b91c2e615e8/ini-daftar-nama-64-terpidana-mati-narkotika [diakses 4 April 2016]

Inge, K. S. (2016), Geng Narkoba Serang Polisi, Bripka Taufik Ditemukan Tewas, (online). Tersedia dalam: <https://m.tempo.co/read/ news/2016/01/19/064737511/geng-narkoba-serang-polisi-bripkataufik-ditemukan-tewas $>$ [diakses 5 April 2016]

Isakoff, M (2011). (online). Tersedia dalam: <http://www.msnbc.msn.com/ id/41257218/ns/us_news-crime_and_courts/t/us-gun-raids-showcartels-work-arizona/> [diakses 5 April 2016]

Lamanauw, N. (2015). Darurat Narkoba, Jokowi: Perkuat Institusi BNN, (online). Berita Satu. Tersedia dalam: <http://www.beritasatu.com/ nasional/308700-darurat-narkoba-jokowi-perkuat-institusi-bnn. html> [diakses 4 April 2016]

Landman, T. (2008). Issues and Methods in Comparative Politics, an Introduction. London: Routledge

Latimes, (2008). Mexico Under Siege, (online). Tersedia dalam: http:// www.latimes.com/world/drug-war/ [diakses 6 April 2016]

Marboe, A (2016). MPR akan bantu perkuat BNN seperti KPK, (online). Tersedia dalam: http://www.antaranews.com/berita/548439/mprakan-bantu-perkuat-bnn-seperti-kpk [diakses 6 April 2016]

Mas'oed, M. (1994). Ilmu Hubungan Internasional: Disiplin dan Metodologi. LP3ES, Jakarta

Mulyadi, A.(2012). Meksiko.Punya.Pabrik.Seragam.Militer. (online). Tersedia dalam: "http://internasional.kompas.com/ $\mathrm{read} / 2012 / 05 / 24 / 22465624 / K a r t e l . N a r k o t i k a$. [diakses 6 April 2016]

Satria, R. (2012). Kekerasan Dan Peredaran Narkoba Studi Kasus: Organisasi Kriminal Di Meksiko. Naskah Publikasi Tesis, Yogyakarta

Supermana, R. (2015). Presiden Jokowi: Indonesia Darurat Narkoba, (online). Tersedia dalam: <http://rri.co.id/post/berita/137516/ nasional/presiden_jokowi_indonesia_darurat_narkoba.html> [diakses 7 April 2016]

Taufiqurrohman. (2015). Alasan Aktivis Koalisi Masyarakat Sipil Tolak Hukuman Mati. (online). Tersedia dalam: <http://news.liputan6. com/read/2220886/alasan-aktivis-koalisi-masyarakat-sipil-tolak- 